\title{
Effect of integrated nutrient management on nitrogen dynamics in soil of rice -potato based cropping sequence
}

\author{
Biplab Pal*, Sajal Pati, Shrikant Badole, Venkateshwarlu Malothu and P. K. Patra
}

Department of Agricultural Chemistry and Soil Science, Bidhan Chandra Krishi Viswavidyalaya, Mohanpur, Nadia -741252 (W.B.), INDIA

*Corresponding author.E-mail: biplab.psb@gmail.com

Received: February 15, 2015; Revised received: June 19, 2015; Accepted: August 16, 2015

\begin{abstract}
The integrated nutrient management (INM) has profound influence on sustaining crop productivity and fertility status of soil. The manurial field experiment was conducted at Paschim Medinipur, West Bengal for evaluating the performance of chemical fertilizer and organic manure on nitrogen availability in different forms in soil and also on the content of nitrogen in different parts of rice (Oryza sativa cv.Annada) and potato (Solanum tuberosum cv. Kufrijyoti) during different growth stages. Application of FYM and $\mathrm{RDF}_{150}$ in combination had good impact on nitrogen dynamics related to crop growth among other treatment combinations. FYM and RDF 150 alone also imparted good impact on nutrient availability and yield of two experiment crops (rice and potato). Experiment revealed that incorporation of commercial concentrated organic manure with RDF 150 exerted good impact besides FYM combination with inorganic fertilizers.
\end{abstract}

Keywords: Concentrated organic manure, INM, Nitrogen dynamics, Transformation

\section{INTRODUCTION}

Rice (Oryza sativa L.) is the main staple food crop of India, covering an area about 39.16 million hectares with total production of 85.59 million tonnes during the year of 2012-2013 (Anonymous, 2014) . In world more than half of seven billion populations are interested to feed that crop especially in Southeast Asia and Latin America. Potato (Solanum tuberosum L.) is the world's fourth most economically important staple food crop in both developed and developing countries due to its yield potential and high nutritive value. Submerged rice soil accounts $20 \%$ of the global production of nitrogen fertilizer._Nitrogen is one of the important essential nutrient which governs the plant growth and nutrition. It's an element which may assure the food and nutritional security of the over increasing population by enhancing production and productivity of crops. In soil mostly nitrogen present in organic form and partly of it in inorganic form. The efficiency of nitrogen fertilizer utilization by rice is directly related to the chemical transformations of nitrogen after the application in soil (Fageria et al., 2003) . Transformations of different nitrogen fractions influence nitrogen availability in soil which governs crop growth and the quality of the produce. The main nitrogen transformation processes in soils are mineralization, immobilization, nitrification, denitrification, ammonia volatilization and biological nitrogen fixation. The physicochemical and biological reactions in soils influence the nitrogen transformation in soil. The importance of soil organic matter to sustain agricultural productivity and to maintain soil quality by adopting new approach i.e. integrated nutrient management which reduces the input cost of inorganic fertilizer and secure the soil health. Sustainable production of crops cannot be maintained by using chemical fertilizers alone due to deterioration in soil physical and biological environments (Khan et al., 2008) . However, new production agrotechnologies i.e. integrated use of both organic manure and chemical fertilizers is the best approach for providing greater stability in production and improving soil fertility status (Islam et al., 2011; Sood, 2007) . Keeping in view, the present investigation was conducted to study the effect of integrated nutrient management (INM) on nitrogen dynamics in soil of rice-potato based cropping sequence.

\section{MATERIALS AND METHODS}

The study was carried out at sub-tropical, sub-humid climate of Paschim Medinipur, West Bengal $\left(22.45^{\circ} \mathrm{N}\right.$ latitude and $86.98^{\circ} \mathrm{E}$ longitude) shows typically red and lateritic soil characteristics (Typic Haplustalf) lies at an elevation of about $81 \mathrm{~m}$ above mean sea level, receives 1500-1600 $\mathrm{mm}$ rainfall annually. It was experimented during two crop seasons (Kharif and Rabi) of two years to study the interaction effect of organic manures along with fertilizers on nitrogen uptake and in the growth and yield of rice (Oryza sativa cv. Annada) including the succeeding crop, potato (Solanum tuberosum cv. Kufri Jyoti). Three levels of 


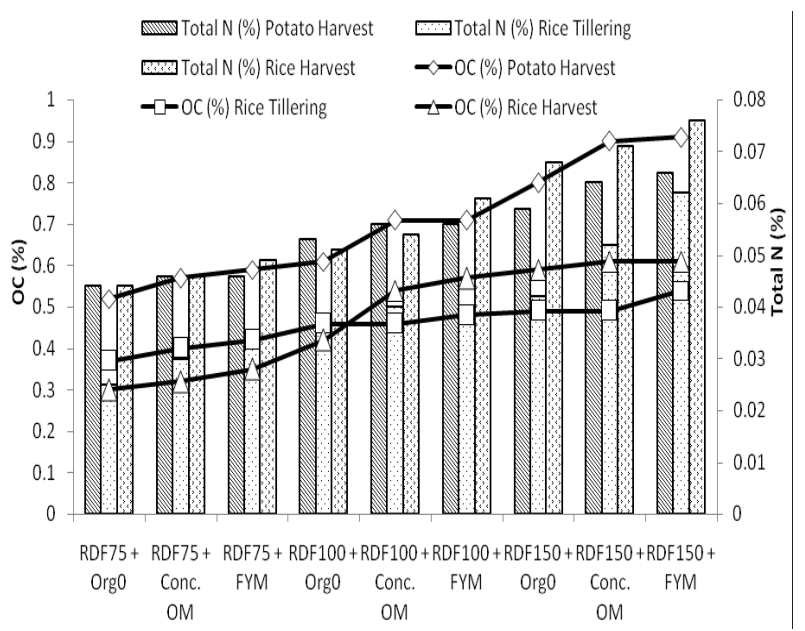

Fig. 1. Effect of different treatment combinations on oxidizable organic carbon and total nitrogen content of soil in rice -potato cropping sequence.

\section{DanmoniumN (Kg ha-1) Potato Harvest \\ A AmnoniumN (Kg ha-l) Rice Harvest \\ $=0$-NitrateN(Kgha-1) Rice Tillering}
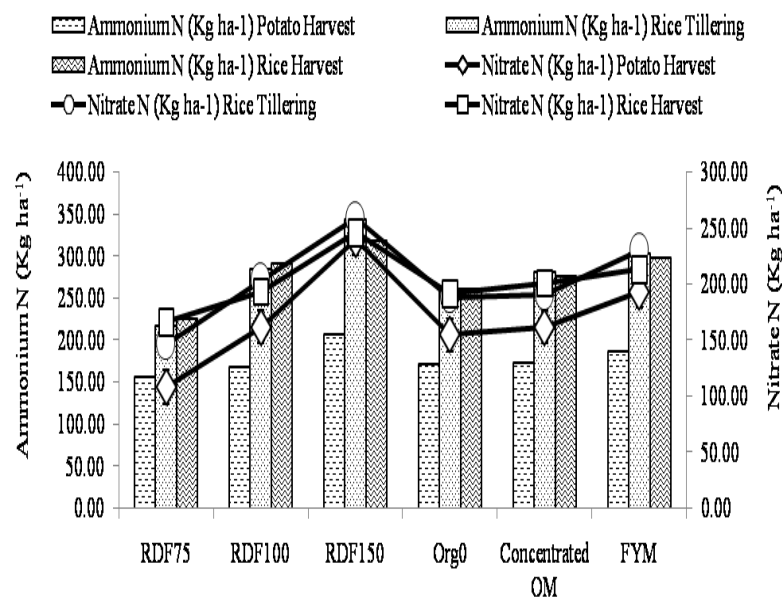

Fig. 2. Effect of different treatments on ammonium and nitrate nitrogen content of soil in rice-potato cropping sequence.

chemical fertilizers $(75 \%, 100 \%$ and 150\% RDF) and organic manures (No organic manure,FYM @20 ton $\mathrm{ha}^{-1}$ and a consortium of concentrated organic manure viz., Max Crystal and Max Power) were applied in the experimented field. The surface soil and plant samples were collected periodically from the experimental plots and were analyzed with the standard methods [ $\mathrm{pH}$ by Jackson (Jackson, 1973), Organic carbon by Walkley and Black method (Walkley and Black, 1934), Total nitrogen by modified kjeldahl method; Exchangeable $\mathrm{NH}_{4}^{+}$and $\mathrm{NO}_{3}{ }^{-}$by Bremner and Keeney method (Bremner and Keeney, 1966), Mineralizable nitrogen through alkaline permanganate method (Subbiah and asija, 1956). Total nitrogen by the micro kjeldahl digestion method]. The pooled data of two years were analyzed in randomized complete block design (RCBD) using the SPSS software.

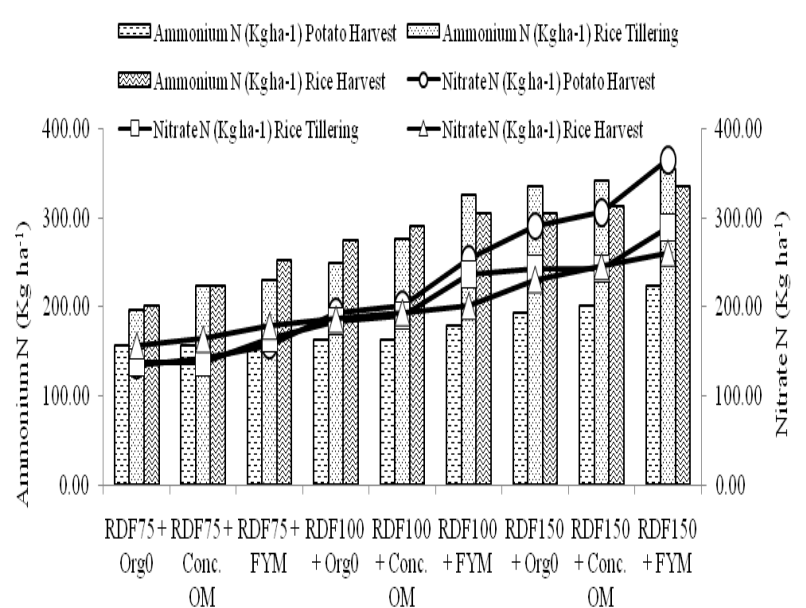

Fig. 3. Effect of different treatment combinations on ammonium and nitrate nitrogen content of soil in rice-potato cropping sequence.

\section{RESULTS AND DISCUSSION}

Oxidizable organic carbon (OC in \%): Application of FYM $(0.74,0.58$ and $0.51 \%)$ and $150 \%$ RDF $(0.87$, 0.50 and $0.60 \%$ ) gave significant positive response for oxidizable organic carbon in comparison to other individual treatments under two factors viz. organic and inorganic manure in potato harvest $(\mathrm{PH})$, rice tillering (RT) and rice harvesting (RH) stage, respectively. Study revealed that treatment combination FYM and $150 \%$ RDF (0.91, 0.54 and $0.61 \%$ in PH, RT and RH stage, respectively) had better response to accumulate higher oxidizable organic carbon than any other treatment interactions. No organic manure in combination with $75 \%$ RDF $(0.52,0.37$ and $0.30 \%$ in $\mathrm{PH}, \mathrm{RT}$ and $\mathrm{RH}$ stage, respectively) gave lower value among other treatment interaction effects (Fig. 1).

Ammonium $\left(\mathrm{NH}_{4}{ }^{+}\right)$and nitrate $\left(\mathrm{NO}_{3}{ }^{-}\right)$form of nitrogen $\left(\mathrm{kg} \mathrm{ha}^{-1}\right)$ : Application of FYM with $150 \%$ $\mathrm{RDF}$ had higher value ( for $\mathrm{NH}_{4}{ }^{+}$form of nitrogen 224, 355.62 and $336 \mathrm{~kg} \mathrm{ha}^{-1}$ and for $\mathrm{NO}_{3}^{-}$form 365.87 , 289.77 and $261.33 \mathrm{~kg} \mathrm{ha}^{-1}$ in $\mathrm{PH}, \mathrm{RT}$ and RH soil, respectively) in comparison to other treatment interactions. Combined application of $75 \% \mathrm{RDF}$ and no organic manure contributed lower $\mathrm{NH}_{4}^{+}(156.80,197.57$ and $201.60 \mathrm{~kg} \mathrm{ha}^{-1}$ in PH, RT and RH soil, respectively) and $\mathrm{NO}_{3}^{-}\left(134.40,138.30\right.$ and $156.80 \mathrm{~kg} \mathrm{ha}^{-1}$, respectively in said sequence) form of nitrogen in both the plant, availed in their different growth stages (Fig. 3). Study also showed that availability of both the form of nitrogen increases in different growing stages of plant viz. $\mathrm{PH}$, RT and RH stage, followed the trend, $150 \% \mathrm{RDF}>$ $100 \% \mathrm{RDF}>75 \% \mathrm{RDF}$ for inorganic factors and in case of organic factors the trend was FYM $>$ Concentrated organic manure $>$ No organic manure (Fig. 2). Similarly, it was reported that increasing rates of NPK application had a favorable influence on exchangeable ammonium nitrogen in soil (Yadav and Singh, 1991) . 

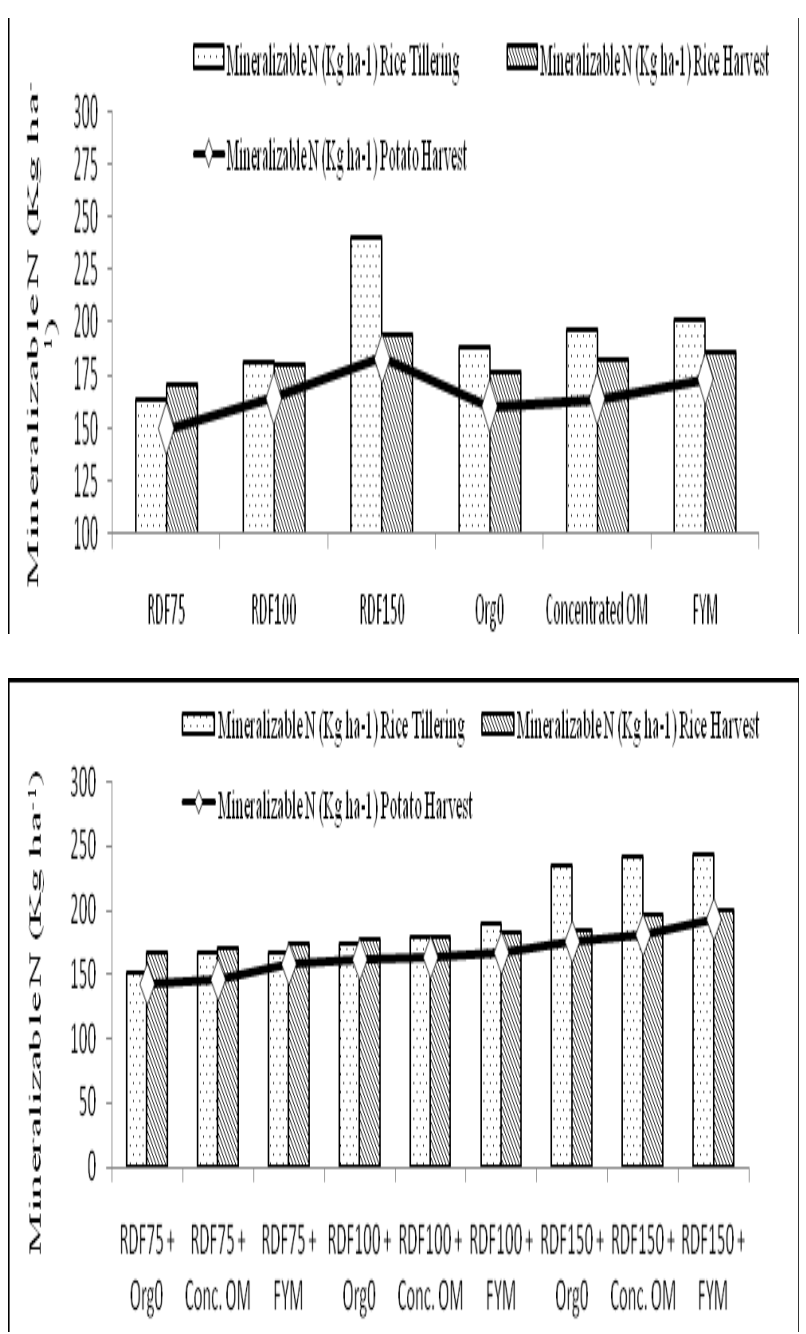

Fig. 4. Effect of different treatments and their combination on mineralizable nitrogen content of soil in rice-potato cropping sequence.

Mineralizable nitrogen $\left(\mathrm{kg} \mathrm{ha}^{-1}\right)$ : Soil mineralizable $\mathrm{N}$, during both stages of rice (tillering and harvesting) and in potato harvesting stage showed an increasing trend under application of different level of chemical fertilizers followed by $75 \% \mathrm{RDF}<100 \% \mathrm{RDF}<150 \%$ RDF. Application of organic treatments in the following order: No organic manure $<$ Concentrated organic manure $<$ FYM showed a positive response on mineralizable nitrogen content for different stages of both crops. In case of both the crop the highest value was observed under application of the highest rate of chemical fertilizer i.e. $150 \%$ RDF in combination with FYM (193.18, 244.54 and $200.08 \mathrm{~kg} \mathrm{ha}^{-1}$ in PH, RT and RH stages, respectively), correspondingly the lowest values were observed under application of the lowest level of chemical fertilizers i.e. $75 \% \mathrm{RDF}$ in combination with no organic manure $\left(143.16,153.07\right.$ and $167.31 \mathrm{~kg} \mathrm{ha}^{-1}$ in PH, RT and RH stages, respectively) (Fig.4).

Total nitrogen (\%): Total nitrogen content increases by the application of higher dose of inorganic and organic fertilizer individually and also with their combined

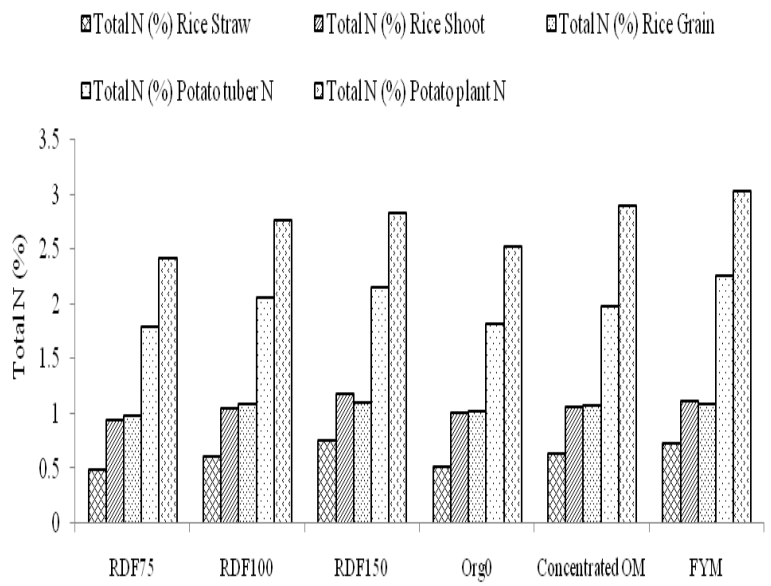

Fig. 5. Effect of different treatments on total nitrogen content in different parts of rice and potato crops.

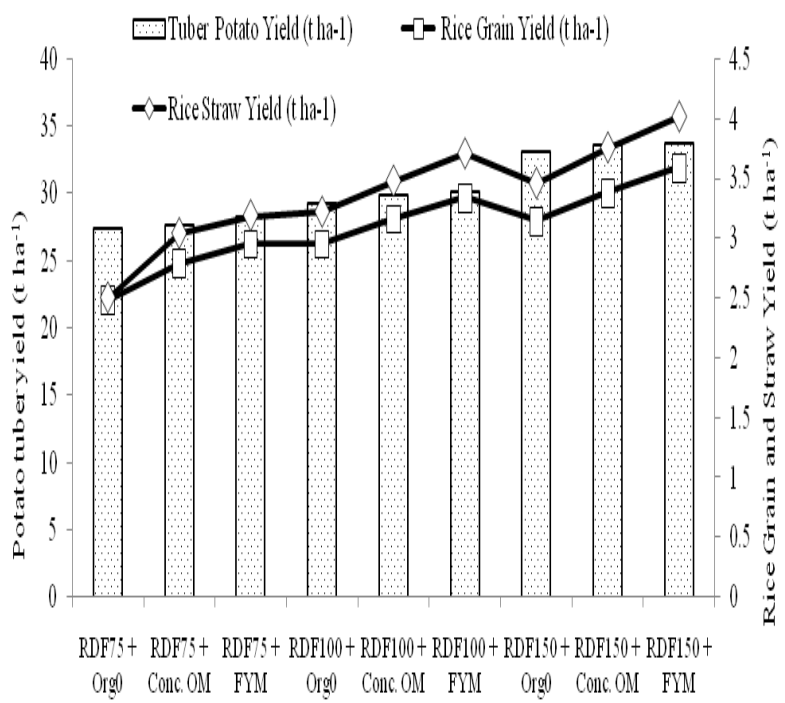

Fig. 6. Effect of different treatment combinations on the yield of rice and potato crops.

application. For both plants, individually $150 \%$ RDF and FYM gave highest value (0.066, 0.062 and $0.076 \%$ in $\mathrm{PH}, \mathrm{RT}$ and $\mathrm{RH}$, respectively) and $75 \% \mathrm{RDF}$ and no organic manure $(0.044,0.025$ and $0.044 \%$ in $\mathrm{PH}, \mathrm{RT}$ and $\mathrm{RH}$, respectively) contribute lowest value of total nitrogen (Fig. 1). Combined application of FYM and $150 \%$ RDF was more effective than inorganic fertilizer in building up the fertility status of soil (Bajpai et al., 2002; Huang et al., 2009).

Total nitrogen content in plant (\%): Application of $150 \% \operatorname{RDF}(0.75,1.1,2.14$ and $2.82 \% \mathrm{~N})$ and FYM $(0.72,1.08,2.25$ and $3.02 \% \mathrm{~N})$ increase the nitrogen content in different parts of two crops viz. rice straw, grain, potato tuber and potato plant, respectively. In case of inorganic factor, trend was followed by $150 \%$ $\mathrm{RDF}>100 \% \mathrm{RDF}>75 \% \mathrm{RDF}$ and for organic factor trend was observed FYM $>$ Concentrated organic 
manure $>$ No organic manure on nitrogen content of two crops (Fig. 5).

Yield ( $\left.\mathbf{t ~ h a} \mathbf{~ h}^{-1}\right)$ : Application of FYM and higher dose of inorganic fertilizer have profound influence on yield of the two said crops viz. rice and potato. Highest yield for potato (33.44 $\left.\mathrm{t} \mathrm{ha}^{-1}\right)$ and rice (3.37 and $3.75 \mathrm{t} \mathrm{ha}^{-1}$ for grain and straw, respectively) were observed due to application of $150 \%$ RDF followed by $100 \%$ RDF and the least yield contributed by $75 \%$ RDF. Application of FYM individually also had good impact on the yield of two crop. In case of applied organic treatments the trend was followed by FYM $\left(30.67,3.29\right.$ and $\left.3.64 \mathrm{t} \mathrm{ha}^{-1}\right)>$ Concentrated organic manure $\left(30.37,3.11\right.$ and $\left.3.43 \mathrm{t} \mathrm{ha}^{-1}\right)>$ No organic manure $\left(29.83,2.86\right.$ and $\left.3.06 \mathrm{t} \mathrm{ha}^{-1}\right)$ on potato tuber, rice grain and straw yield, respectively. 150\% RDF and FYM (33.70, 3.59 and $4.02 \mathrm{t} \mathrm{ha}^{-1}$ ) contributes maximum yield among different treatment interactions on potato tuber, rice grain and straw yield, respectively (Fig.6). Parihar (2004) also found that application of high dose of RDF along with FYM increase the yield of rice.

\section{Conclusion}

Combined application of organic amendments along with inorganic fertilizers, an integrated approach which exerted significant influence on availability of different forms of $\mathrm{N}$ (total $\mathrm{N}$, mineralizable $\mathrm{N}$, ammonium $\mathrm{N}$, nitrate $\mathrm{N}$ ) and growth and yield of the said crops. It also influences the nitrogen availability to plant. The results obtained by addition of $150 \%$ RDF along with FYM followed by treatment combination $150 \% \mathrm{RDF}$ and concentrated organic manure exerted good result on $\mathrm{N}$ availability and yield of the crops. In such circumstances when FYM availability remains a problem then commercially available sea weed extract based concentrated organic manures could be a remunerative for farmers.

\section{REFERENCES}

Anonymous, (2014). Area and production of rice in India. Retrieved from http://www.indiastat.com.
Bajpai, R.K., Upadhyay, S.K. and Tripathi, R.S. (2002). Productivity and economics of rice-wheat cropping system under integrated nutrient supply system. J. Ind. Agron., 47: 20-25.

Bremner, J.M. and Keeney, D.R. (1966). Determination of exchangeable ammonia, nitrate and nitrite by extraction distillation method. Soil Sci. Am. Proc. 30: 577-587.

Fageria, N.K., Slaton, N.A. and Baligar, V.C. (2003). Nutrient management for improving lowland rice productivity and sustainability.Adv. Agron.80: 63-152.

Huang, Q.R., Hu, F., Huang, S., Li, H.X., Yuan, Y.H., Pan, G.X. and Zhang, W.J. (2009). Effect of long-term fertilization on organic carbon and nitrogen in a subtropical paddy soil.Pedosphere. 19: 727-734.

Islam, M.M., Karim, A.J.M.S., Jahiruddin, M., Majid, N.M., Miah, M.G., Ahmed, M.M. and Hakim, M.A. (2011). Effects of organic manure and chemical fertilizers on crops in the radish-stem amaranth-Indian spinach cropping pattern in homestead area.Aust. J. Crop Sci. 5:1370-1378.

Jackson, M.L. (1973). Soil Chemical Analysis.Prentice Hall of India Pvt. Ltd. New Delhi.

Khan, M.S., Shil, N.C. and Noor, S. (2008). Integrated nutrient management for sustainable yield of major vegetable crops in Bangladesh. Bangladesh. J. Agric. Environ.4: 81-94.

Parihar, S.S. (2004). Effect of crop establishment method, tillage, irrigation and nitrogen on production potential of rice (Oryza sativa L.)-wheat (Triticumaestivum L.) cropping system.J. Ind. Agron. 49: 1-5.

Sood, M.C. (2007). Integrated nutrient supply and management for potato production in Mid Hills of Shimla.Potato J.34: 101-102.

Subbiah, B.V. and Asija, G.L. (1956).A rapid procedure for the estimation of available nitrogen in soils.Current Science. 25: 259-260.

Walkley, A.J. and Black, I.A. (1934). Estimation of soil organic carbon by chromic acid titration method. Soil Sci.37: 29-38.

Yadav, M.D. and Singh, K.D. (1991). Transformation of applied nitrogen in relation to its availability to sugarcane in a calcareous soil. J. Ind. Soc. Soil Sci.39: 292-297. 